\title{
能動制御を用いた自動車用シートにおける乗員頭部の振動低減に関する研究*
}

\author{
大田 慎一郎*1, 西山 修二*1
}

\section{Investigation of Vehicle Seat with an Active Control System to Minimize Vertical Vibrations to the Head}

\author{
Shinichiro OTA ${ }^{* 1}$ and Shuji NISHIYAMA \\ ${ }^{* 1}$ Faculty of Computer Science and System Engineering, Okayama Prefectural University \\ 111 Kuboki, Soja-shi, Okayama, 719-1197, Japan
}

This paper describes an active control system intended to minimize the vertical vibrations transferred from the vehicle seat to the head. This system controls mechanical properties effectively such as the spring constants and damping coefficients of the seat cushion by using an optimized algorithm that comprises vibration analysis and an optimization method. To estimate an efficient optimized algorithm, we investigate reduction rates of the vertical vibrations on the head using a vibration analysis based on a model for the seat-occupant system when the mechanical properties are controlled in a part of seat cushion. These results showed relationships between the reduction rates and the mechanical properties of the each seat cushion optimized at frequency band. In conclusion, the effective optimized algorithm using these relationships enable to reduce the vertical vibrations on the head while reducing the number of seat cushion control.

Key Words : Vibration Control, Human Dynamics, Active Control, Seat Ride Comfort, Simulation

1. 緒 論

自動車の快適性に対する要求は年々厳しくなり，快適性向上への取り組みの一つとして, 乗員の上下方向の共振 点である $4 \sim 8 \mathrm{~Hz}$ の振動を低減させるようにシートの設計が行われてきた ${ }^{(1)(2)}$. しかしながら , 乗員の体形や姿勢 による違いから共振点に変化が生じ(3), さらに路面からの振動は経時的に変化するため, 最適な振動設計が行われ ているとはいえない．また，We ら ${ }^{(4)}$ や Han ら ${ }^{(5)}$ はシート下に従来のパッシブサスペンションにアクティブサスペ ンションを追加もしくは置き換え，振動低減を試みている．これらの研究は，シート座面からの振動のみを考慮 しているが, 振動はシート座面のみならずステアリングホイールやフットレストからも伝達するため, 振動低減 をさらに向上させるためにはシート各部のクッション特性を制御する必要がある .

そこで, 筆者らは, 振動低減のためにシート各部位のクッション特性を能動制御するシステムを提案してきた (6)(7). 本システムは, 振動の周波数帯毎に乗員が最も振動低減するように , シート各部のクッション特性のライブ ラリを最適化法により構築する . 次に , 継続的な振動が人体に影響を及ぼすため ${ }^{(8)}$, 任意の時間 , 継続的に測定さ れた車体振動の振動数を加速度センサにより検知する . 光して, 最大の振幅が検知されている周波数帯を対象と

し，空気駆動式クッション等によりシートのクッション特性をライブラリに基づき能動制御する ${ }^{(6)}$. 前報 ${ }^{(7)}$ では， 乗員一シート系の連成振動としてモデル化した振動モデルと最適化法を併用した最適化アルゴリズムを構築し，最 適化アルゴリズムの有用性について検証し，乗員一シート系の能動制御の可能性を示した．しかしながら , シー トの能動制御において, 加速度センサにより検知された振動数に応じてリアルタイムに振動を低減させる必要が あるため, クッションの制御箇所を最適化しつつ, 効率的に制御することか課題である .

* 原稿受付 2011 年 10 月 18 日

${ }^{* 1}$ 正員, 岡山県立大学情報工学部（テ719-1197 岡山県総社市窪木 111）

E-mail: ota@ss.oka-pu.ac.jp 
したがって, 本研究の目的は, 人体を保持するシートの各クッションが周波数毎の振動低減に及ぼす影響を調査 し，弚れに基づきシートクッションを制御した場合における振動低減効果を明確化することである．弚こで，運 転動作に影響を与えると考えられる頭部に着目し, 支持点のクッション毎に最適化アルゴリズムを適用させ , 各 クッションの振動低減率を明確にする。光して, 光の振動低減率に基づいて制御対象となるクッションを決定さ せた場合における乗員の上下方向加速度の低減率を理論的に解析する。

\section{2. 最適化アルゴリズム}

\section{$2 \cdot 1$ 振動モデル}

乗員 - シート系の振動モデルにより，解析を行う．振動モデルを図 1 に示す . 図 1(a) は乗員 - シート系の振動 モデル，图1(b) は座標系を乥れす．また，図に用いている主な記号の説明を以下に示す．

\section{記 号 説 明}

$m_{i}(i=1,2 \cdots 4)$ : 頭部と頸部，胴体部，大腿部，下腿部の質量

$I_{i}(i=1,2 \cdots 4):$ 乗員各部の慣性モーメント

$\theta_{i}(i=1,2 \cdots 4):$ 乗員各部の回転変位

$\theta_{0}:$ シート角度

$\beta:$ フットレスト角度

$\xi, \zeta:$ 腰ジョイント点の $x, z$ 方向変位

$x_{i}(i=1,2 \cdots 4)$ : 乗員各部重心の $x$ 座標

$z_{i}(i=1,2 \cdots 4)$ : 乗員各部重心の $z$ 座標

$k_{i}(i=1,2 \cdots 5):$ 乗員支持点のばね定数

$c_{i}(i=1,2 \cdots 5):$ 乗員支持点の粘性減衰係数

$T_{i}(i=1,2,3):$ 頸部, 腰部, 膝部関節のフリクションモーメント

$\delta_{i}(i=1,2 \cdots 5):$ ばね・ダンパの動的たわみ

$\delta_{i, 0}(i=1,2 \cdots 5):$ ばね・ダンパの初期たわみ

$l_{i}(i=1,2 \cdots 7):$ 乗員各部の寸法

$l_{k}, l_{j}, l_{o}, l_{p}, l_{q}:$ シート各部の寸法

本研究で取り扱う乗員 - シート系の振動モデルは, 着座姿勢や体格を検討可能とするため, 図 1 に示すように 頭部と頸部，胴体部，大腿部および下腿部の四つの岡体としてモデル化し，各部の重心に質量と慣性モーメント を考慮する。

ここで, 人体各部のセグメント長，セグメント質量，セグメント重心位置，セグメント慣性モーメント等は幾 何学的特性が明らかな JM50 ダミー (日本人成人男子の身長, 体重などの 50 パーセンタイル值を有する) の值を 使用する . また , 頸 , 腰および膝の連結点はピンジョイントとし , 谷の関節部にフリクションモーメントとして , 筋肉の緊張をほぐした弛緩状態における乗員を想定し, 頸, 腰, 膝での各関節の相対角速度に比例したダンピン グ特性を考慮する ${ }^{(7)(9)(10)}$.

乗員 - シート系の支持点のばね定数・粘性減衰定数の值 $\left(k_{5}, c_{5}, k_{1,0} \sim k_{4,0}, c_{1,0} \sim c_{4,0}\right)$ は, 図 1 に示す乗員 シート系のモデルにおいてフロアを上下に正弦波加振し，人体の振動応答特性 ${ }^{(11)(12)}$ を考慮して，同定されている． シートは, シートクッション , シートバッククッションを考慮する . 胴体部はシートバック上部および下部の 2 点で支持するものとし，乗員 - シートの支持点はばねとダンパでモデル化する . 乗員 - シートの支持点は密着して いるものとし , シートバック角度と乗員胴体角度は初期值が等しいものとする . また , フットレストによる影響 も考慮し , フロアと足との接触間をばねとダンパでモデル化する . 以上のような , 各質量の上下, 前後および回 転運動からなる 6 自由度のモデルを用いて, 乗員 - シート系においてシートバック 2 点とシート座面 2 点のクッ ション特性を評価する. 
乗員 -シート系の諸元を次に示す .

$m_{1}=5.3214 \mathrm{~kg} \quad, m_{2}=26.4894 \mathrm{~kg}$

$I_{1}=0.036652 \mathrm{~kg} \cdot \mathrm{m}^{2} \quad, I_{2}=0.7938 \mathrm{~kg} \cdot \mathrm{m}^{2} \quad, I_{3}=0.20384 \mathrm{~kg} \cdot \mathrm{m}^{2} \quad, I_{4}=0.1911 \mathrm{~kg} \cdot \mathrm{m}^{2}$

$l_{1}=0.152 \mathrm{~m} \quad, l_{2}=0.196 \mathrm{~m} \quad, l_{3}=0.278 \mathrm{~m} \quad, l_{4}=0.149 \mathrm{~m}$

$l_{5}=0.278 \mathrm{~m} \quad, l_{6}=0.286 \mathrm{~m} \quad, l_{7}=0.126 \mathrm{~m} \quad, l_{k}=0.424 \mathrm{~m}$

$l_{j}=0.350 \mathrm{~m} \quad, l_{o}=0.799 \mathrm{~m} \quad, l_{p}=0.050 \mathrm{~m} \quad, l_{q}=0.163 \mathrm{~m}$

$\theta_{0}=110.0^{\circ} \quad, \beta=0.0^{\circ} \quad, k_{5}=30.0 \mathrm{kN} / \mathrm{m} \quad, c_{5}=30.0 \mathrm{~N} \cdot \mathrm{s} / \mathrm{m}$

シート系の初期値を次に示す .

$\xi_{0}=0.07 \mathrm{~m} \quad, \zeta_{0}=0.11 \mathrm{~m} \quad, \theta_{1,0}=100.0^{\circ} \quad, \theta_{2,0}=110.0^{\circ} \quad, \theta_{3,0}=10.0^{\circ} \quad, \theta_{4,0}=318.0^{\circ}$

シート系のクッション特性の標準值を次に示す.

$k_{1,0}=135.0 \mathrm{kN} / \mathrm{m} \quad, k_{2,0}=165.0 \mathrm{kN} / \mathrm{m} \quad, k_{3,0}=36.0 \mathrm{kN} / \mathrm{m} \quad, k_{4,0}=24.0 \mathrm{kN} / \mathrm{m}$

$c_{1,0}=675 \mathrm{~N} \cdot \mathrm{s} / \mathrm{m} \quad, c_{2,0}=825 \mathrm{~N} \cdot \mathrm{s} / \mathrm{m} \quad, c_{3,0}=180 \mathrm{~N} \cdot \mathrm{s} / \mathrm{m} \quad, c_{4,0}=120 \mathrm{~N} \cdot \mathrm{s} / \mathrm{m}$

本報では，これらの標準值から周波数帯域毎に最適なクッション特性 $k_{i}, c_{i}(i=1,2 \cdots 4)$ を同定する .なお,$k_{i}$ と $c_{i}$ の関係は空気駆動式クッションの特性により決定されるが，簡単のため線形関係と仮定し， $c_{i}=k_{i} / 200(i=1,2 \cdots 4)$ のように設定する．また，弚の他の変数の初期值は 0 とする .

\section{$2 \cdot 2$ 振動解析}

本解析では, 乗員系のフリクションモーメント, 支持点の変位，作用力などを計算し，運動方程式を解く ${ }^{(7)}$. 系 を支配する運動方程式は連立 6 元 2 階常微分方程式の初期值問題である. 変数変換により連立 12 元 1 階常微分方 程式として数值計算する.解法として Runge-Kutta-Gill 法により時間ステップごとの各変数と产の微分係数の值を 求める. 計算回数と計算きざみ幅を光れ光れ 5000 回，0.001 秒とし，数值計算は倍精度で行う.

シートに発生する振動として,$t=0$ で変位および変位の時間微分が 0 になるように式 (1) を入力して周波数応答 特性を調べる。

$$
z(t)=\left(\frac{a}{2}\right)\left(1-\cos 2 \pi t f_{n}\right)
$$

ここで, $a$ : 全振幅, $t$ : 時間, $f_{n}$ : 周波数であり, $a=0.005 \mathrm{~m}$ とする . また，周波数応答特性の計算にあたり，本研 究で取り扱う振動特性は低周波数域で共振現象が発生し変化が著しく，高周波数では変化が緩慢である.したがっ て , 周波数 $f_{n}$ は式 (2) で示すアルゴリズムにより決定する .

$$
\begin{gathered}
f_{n}=10^{A B L} \quad\left(n=1,2 \cdots N_{d}\right) \\
A B L=\log \left(\frac{f_{\text {max }}}{f_{\text {min }}}\right) \cdot \frac{n-1}{N_{d}-1}
\end{gathered}
$$

ここに, $N_{d}$ は周波数軸の最大離散点数, $f_{\max }, f_{\min }$ は周波数の上限と下限を示し, 弚れ光れ $f_{\max }=20 \mathrm{~Hz}, f_{\min }=1$ $\mathrm{Hz}, N_{d}=50$ とする.式 (2) で決定した周波数について計算を実行し，時間ステップごとの加速度の二乗平均平方根 (rms 值) を求め, 求めた值を谷の周波数に対する代表値とする.本手法により，周波数軸の低周波数域における離 散点が多数とれ，低周波数域の振動特性を詳細に把握できる .

図 2 は, 初期条件における乗員 - シート系の上下方向振動伝達特性と頭部加速度比の実験結果 ${ }^{(12)}$ を示す . 横軸 は周波数，縦軸は各帯域の乗員各部の加速度をフロア加速度て除した加速度比を示す . なお , 実験は , シート座面 およびシートバックの角度が $10.0^{\circ}, 110.0^{\circ}$ に設定されているシートを振動台の上に設置し，成人男性 (体重 54 $\mathrm{kg}$ )をシートに着座させ , 加速度変換器が取り付けられたイソプレン系樹脂を頭頂部に装着した状態で測定され ている. 入力信号は, 振動数 $2 \sim 20 \mathrm{~Hz}$, 全振幅 $0.005 \mathrm{~m}$ の正弦波振動とし, 対数掃引されている.これより, 解 析結果において，周波数 $4.1 \mathrm{~Hz}$ で極大值 2.7 に達し，周波数の増加とともに漸減変曲しつつ減衰している．また， 実験結果では, 周波数 $4.0 \mathrm{~Hz}$ で極大値 2.9 を示し, 周波数の増加とともに漸減変曲しつつ減衰しており, 本解析 結果と傾向が一致し，乗員 - シート系のモデル化および解析手法の妥当性がわかる . 


\section{$2 \cdot 3$ 最適化法}

本システムにおいて，加速度センサにより測定された振動数に応じてシートのクッション特性を能動制御する． 乥こで, 対象とする周波数帯域において低周波数帯域を詳細に制御するため, 式 (2)に基づいて周波数の検査帯域 $(1 \sim 20 \mathrm{~Hz})$ を 8 分割する.表 1 は，分割した周波数帯域 $F R E_{i}(i=1,2 \cdots 8)$ と帯域の代表周波数を示す.

この周波数帯域毎にシートの最適なクッション特性を滑降シンプレックス法により決定する . 滑降シンプレック ス法は, 関数の勾配を用いずに目的関数のみを用いるため, 複雑系の最適化に適している. 本手法において, 式 (3) で示す誤差関数に基づき，最適なシートのクッション特性を最適化する .

$$
E R R O R=\sqrt{\frac{1}{N_{a}} \int_{f_{i}^{*}}^{f_{i+1}^{*}}\left(\frac{\mathrm{VAR}_{c a l}-T A R \cdot \mathrm{VAR}_{s t a}}{T A R \cdot \mathrm{VAR}_{\text {sta }}}\right)^{2} d f}
$$

$\mathrm{VAR}_{s t a}, \mathrm{VAR}_{c a l}$ は標準值と最適化時における解析値を示す．また， $N_{a}$ は積算回数であり，対数的に分割している ため周波数帯域により異なる值を示す.式(3)において, 目標値である TARが 0 の場合, ERROR は無限大となる ため，標準値で解析した $\mathrm{VAR}_{s t a}$ の $10 \%$ となる 0.1 を設定する. ERRORが小さいほど任意の周波数帯に対して目 標値に近く，振動低減されていることを示す．

ここで, アクチュエータ等の性能によりクッション特性の変動範囲の制限か想定されるが, 簡単のため標準值を 基準としたクッション特性の変動比率を $1 / 2.0 \sim 2.0$ に設定し, 弚の各領域内で $E R R O R$ が最小になるようにシート のクッション特性を推定する.なお，滑降シンプレックス法の解析条件は，反射係数を 0.8 , 縮小係数を 0.5 , 拡 大係数を 2.0 , 繰り返し計算回数を 200 とする.また, 解析時に反射, 縮小, 拡大が繰り返される過程で, 変動領 域外のシートパラメータが検知された場合は，㚇のシートパラメータは変動領域の境界内に戻され，反射，縮小， 拡大が繰り返される。

\section{3. 計算結果および考察}

\section{$3 \cdot 1$ クッション特性と振動低減率の関係}

各部位のクッション特性が周波数毎の振動低減に及ぼす影響を調べるためにクッション毎に単独で最適化した 場合の頭部の振動低減率を明らかにする．

図 3 は, 周波数帯 $F R E_{i}(i=1,2 \cdots 8)$ に対してシート部位毎に最適化されたシートのクッション特性と基準値 の変動比率 $k_{1} / k_{1,0} \sim, k_{4} / k_{4,0}$ を示す.なお, 各点の周波数は, 表 1 に示す周波数帯 $F R E_{i}$ における周波数の平均 を代表値とする . 図 3 から $k_{1} / k_{1,0} \sim k_{4} / k_{4,0}$ は, 各振動数に対して乥れ光れ固有の最適值を有し, 設定した変動比 率である領域 1/2.0 2.0の範囲内で変化していることがわかる .

図 4 は, 標準条件と最適化時における $F R E_{1} \sim F R E_{8}$ の周波数帯域毎の平均加速度比と標準值からの振動低減率 を示す .なお，各点の周波数は，表 1 に示す周波数帯 $F R E_{i}$ における周波数の平均を代表値とする.

図 4 (a) より, 平均加速度比は, 図 2 で示す加速度比と同樣に $4 \mathrm{~Hz}$ 周辺において極大值に達し, 周波数の増加 とともに漸減変曲しつつ減衰している .さらに , シートクッションの後部 $k_{3}, c_{3}$ を最適化した場合にすべての周 波数帯において, 平均加速度比がもっとも低下していることがわかる . これは, 図 1(a) からわかるようにシート クッションの後部は上下方向の振動に作用し, さらに頭部の鉛直線上の近くに位置し, 頭部の振動特性に大きく 影響を及ぼしているものと考えられる．

図 4(b) より， $k_{1}, k_{2}, k_{3}$ を最適化した場合は $5.4 \mathrm{~Hz}$ において， $k_{4}$ を最適化した場合は $7.8 \mathrm{~Hz}$ においてもっと も高い振動低減率を示し, 各シートのクッション特性によって振動低減率のピーク值が異なることがわかる . 一 方, $F R E_{1} \sim F R E_{3}$ と $F R E_{6} \sim F R E_{8}$ の周波数帯域では $k_{3}, k_{4}, k_{1}, k_{2}$ の順で, $F R E_{4}$ では $k_{3}, k_{1}, k_{4}, k_{2}$ の順で， $F R E_{5}$ では $k_{3}, k_{2}, k_{1}, k_{4}$ の順で振動低減率が高いことがわかる .

以上より，各シート部位のクッション特性により振動低減率の特性が異なることが明らかとなった．よって，こ れらを考慮して制御するクッションを選定することにより，効率的な振動低減が可能となるものと考えられる． 


\section{$3 \cdot 2$ 振動低減率を考慮した最適化アルゴリズム}

各シート部位のクッション特性により振動低減率の特性が異なることを考慮し, シートのクッションを最適化

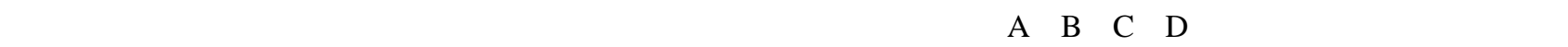
化 A〜D で制御するクッションを振動低減率の高い順とし，表 2 に示すように設定する．

図 5 は，周波数帯 $F R E_{i}(i=1,2 \cdots 8)$ に対して最適化 $\mathrm{A} \sim \mathrm{D}$ におけるシートのクッション特性と基準值の変動 比率 $k_{1} / k_{1,0} \sim k_{4} / k_{4,0}$ を示す . なお , 各点の周波数は, 表 1 に示す周波数帯 $F R E_{i}$ における周波数の平均を代表值 とする . また , 最適化されていないシートクッションのパラメータは, 標準值からの変動がないため $k_{i} / k_{i, 0}=1 の$ 一定值を示す. 図 5 から $k_{1} / k_{1,0} \sim k_{4} / k_{4,0}$ は, 各振動数に対して光れ光れ固有の最適值を有し, 設定した変動比率 である領域 1/2.0 2.0 の範囲内で変化していることがわかる . また , 図 5(c) より, $k_{3} / k_{3,0}$ は最適化 A D Dおいて すべて一致していることがわかる.これは, シートクッションの後部がもっとも振動低減率に寄与し, 周波数帯 毎に他のクッション特性に関係なく最適値を有することを示している .

図 6 は, 標準条件と最適化 $\mathrm{A} \sim \mathrm{D}$ における $F R E_{1} \sim F R E_{8}$ の周波数帯域毎の平均加速度比と標準値からの振動低 減率を示す. 図 6(a) より, 標準值における平均加速度比に対して, 最適化 A，B，C，D と最適化するクッション の数を増やすほど，振動低減の効果か顕著に現れる．また，すべての条件に対して，3.74 Hz において極大值に達 し, 周波数の増加とともに漸減変曲しつつ減衰している.この傾向は標準值における平均加速度比と一致してい る .これは, 人体の共振点が $4 \mathrm{~Hz}$ 周辺にあり ${ }^{(10)}$, 共振点近傍における振動の増加が要因と考えられる . 一方 , 3.74 $\mathrm{Hz}$ の周波数における平均加速度比は最適化 A , B , C , D の条件で, 弚れ攵れ $0.75,0.79,0.84,0.90$ の加速度比 の低減が可能であり, 最適化するシートのクッション数を多くすることで, 人体の共振点の振動を低下させること が可能となる .

図 6(b)より，最適化 A，B，C，Dの条件で，光れ光れ最大で $47.2 \%(5.4 \mathrm{~Hz}) ， 58.7 \%(5.4 \mathrm{~Hz}) ， 59.8 \%(5.4 \mathrm{~Hz})$ ， $67.5 \%(5.4 \mathrm{~Hz})$ ，最小で $3.0 \%(1.21 \mathrm{~Hz}), 3.2 \%(1.21 \mathrm{~Hz}), 3.5 \%(1.21 \mathrm{~Hz}), 3.7 \%(1.21 \mathrm{~Hz})$ の加速度の振動低減が可

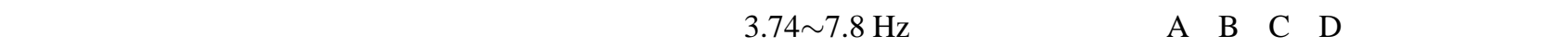
れ, 最適化 A は $32.8 \sim 47.2 \%$, 最適化 B は 34.7〜 58.7\%, 最適化 C は $37.0 \sim 59.8 \%$, 最適化 D は $39.4 \sim 67.5 \%$ となり，最適化 $\mathrm{A} \sim \mathrm{C}$ はすべてのシート部位を制御した最適化 D より低下するが， $30 \%$ 以上の振動低減率を有し ていることか確認できる .

以上のように, 各クッション特性が及ぼす振動低減率を考慮したクッション制御ができるため, クッションの制 御箇所を最適に制御しつつ, 効率的な振動低減の可能性が示された .

\section{4. 結 論}

乗員 - シート系の振動モデルを用いて車両床上から乗員頭部に伝達される振動を低減するための理論的な研究 を行った . 本研究により明らかになった事項をまとめると，次のとおりである .

(1) 各シート部位のクッション特性が振動低減へ及ぼす影響について，振動低減率を用いて明確化した .

(2) クッション毎の振動低減へ及ぼす影響を考慮することで, クッションの制御箇所を制御しつつ，効率的な振 動低減の可能性が示された .

本研究で開発した能動制御システムの今後の課題として, シートのクッション特性の変動值はシート制御を実 現可能とするアクチュエータ等の性能に依存することから，これを考慮した最適化法を構築する必要がある .さ らに, 乗り心地をさらに向上させるためには頭部だけでなく , ブレーキやアクセル等のペダル操作に重要となる 下腿部，ステアリングホイールの操作で重要となる上腕や前腕の振動低減か課題であり，今後検討していきたい . 


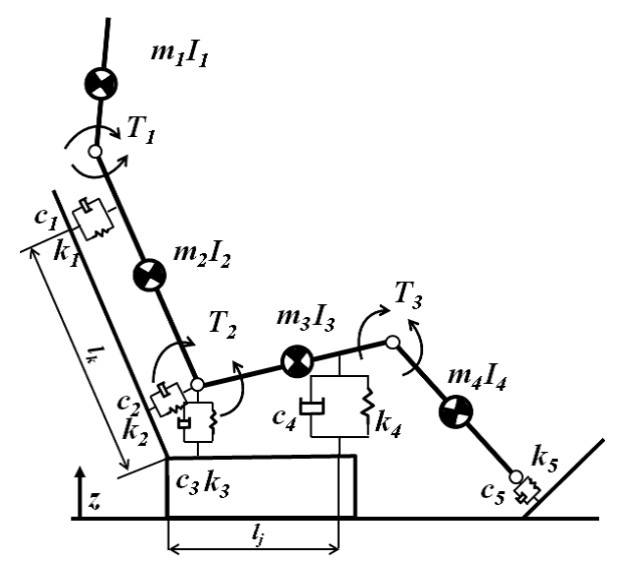

(a) Mechanical properties

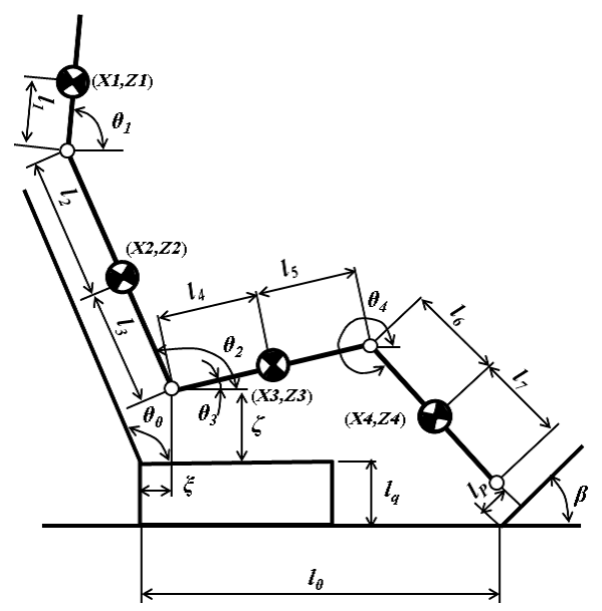

(b) Coordinate system

Fig. 1 Vibration model of seat-occupant system

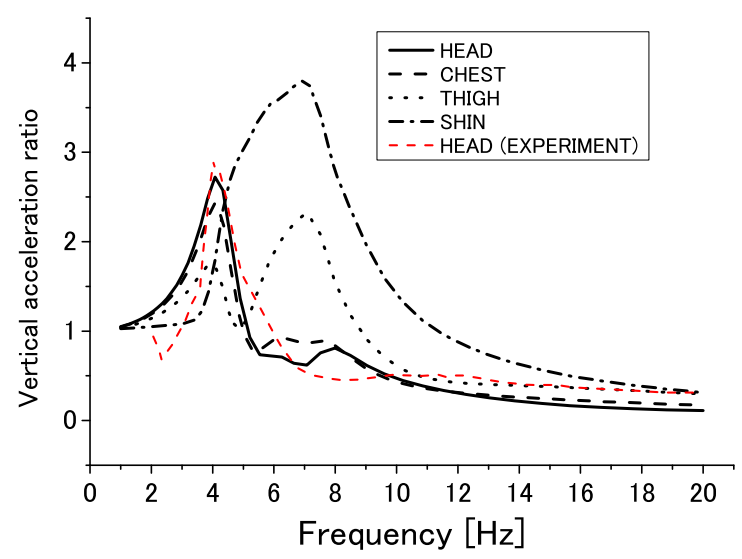

Fig. 2 Vibration characteristics with the standard condition

Table 1 Frequency bands and representing frequency

\begin{tabular}{|c||c|c|}
\hline & Frequency band & Representing frequency \\
$i$ & $f_{i}^{*} \leq F R E_{i}<f_{i+1}^{*}[\mathrm{~Hz}]$ & {$[\mathrm{Hz}]$} \\
\hline 1 & $1.00 \leq F R E_{1}<1.45$ & 1.21 \\
2 & $1.45 \leq F R E_{2}<2.11$ & 1.80 \\
3 & $2.11 \leq F R E_{3}<3.08$ & 2.59 \\
4 & $3.08 \leq F R E_{4}<4.47$ & 3.74 \\
5 & $4.47 \leq F R E_{5}<6.50$ & 5.40 \\
6 & $6.50 \leq F R E_{6}<9.46$ & 7.80 \\
7 & $9.46 \leq F R E_{7}<13.75$ & 11.25 \\
8 & $13.75 \leq F R E_{8}<20.00$ & 16.77 \\
\hline
\end{tabular}




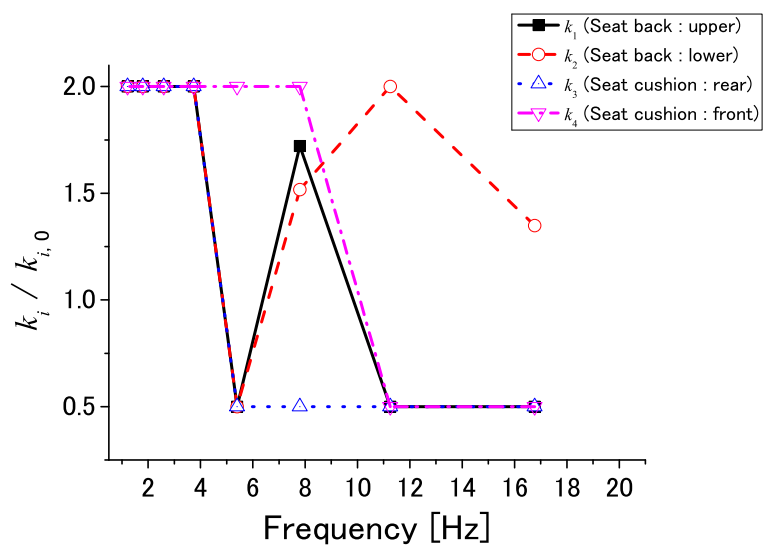

Fig. 3 Mechanical properties at a part of the seat cushions optimized

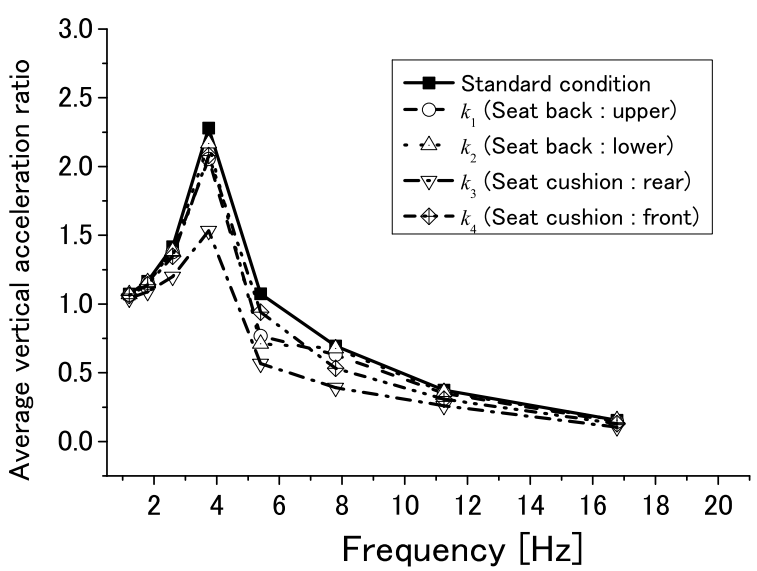

(a) Average vertical acceleration ratio

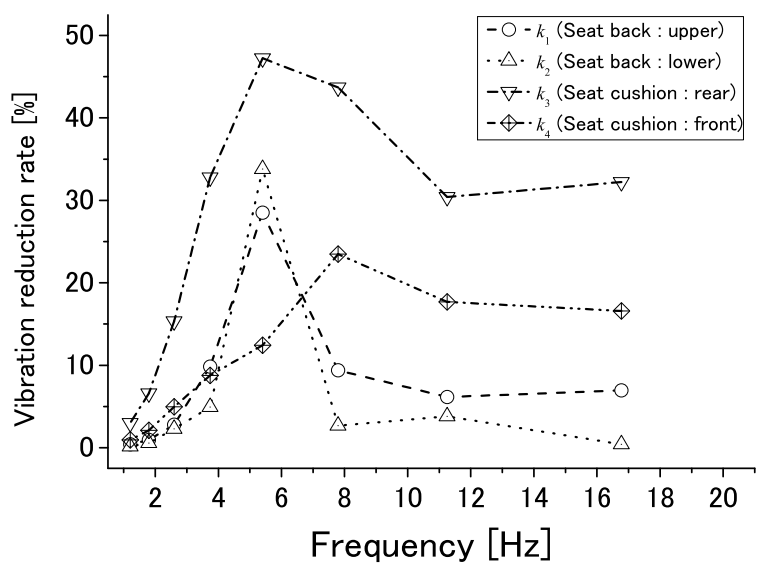

(b) Reduction rates of the vertical acceleration

Fig. 4 Vibration characteristics in a part of the seat cushions optimized

Table 2 Seat cushions in each frequency band used by the optimized algorithm

\begin{tabular}{|c||c|c|c|c|}
\hline Frequency band & Optimization A & Optimization B & Optimization C & Optimization D \\
\hline $1.00 \leq F R E_{1}<1.45$ & $k_{3}, c_{3}$ & $k_{3}, k_{4}, c_{3}, c_{4}$ & $k_{1}, k_{3}, k_{4}, c_{1}, c_{3}, c_{4}$ & $k_{1} \sim k_{4}, c_{1} \sim c_{4}$ \\
$1.45 \leq F R E_{2}<2.11$ & $k_{3}, c_{3}$ & $k_{3}, k_{4}, c_{3}, c_{4}$ & $k_{1}, k_{3}, k_{4}, c_{1}, c_{3}, c_{4}$ & $k_{1} \sim k_{4}, c_{1} \sim c_{4}$ \\
$2.11 \leq F R E_{3}<3.08$ & $k_{3}, c_{3}$ & $k_{3}, k_{4}, c_{3}, c_{4}$ & $k_{1}, k_{3}, k_{4}, c_{1}, c_{3}, c_{4}$ & $k_{1} \sim k_{4}, c_{1} \sim c_{4}$ \\
$3.08 \leq F R E_{4}<4.47$ & $k_{3}, c_{3}$ & $k_{1}, k_{3}, c_{1}, c_{3}$ & $k_{1}, k_{3}, k_{4}, c_{1}, c_{3}, c_{4}$ & $k_{1} \sim k_{4}, c_{1} \sim c_{4}$ \\
$4.47 \leq F R E_{5}<6.50$ & $k_{3}, c_{3}$ & $k_{2}, k_{3}, c_{2}, c_{3}$ & $k_{1} \sim k_{3}, c_{1} \sim c_{3}$ & $k_{1} \sim k_{4}, c_{1} \sim c_{4}$ \\
$6.50 \leq F R E_{6}<9.46$ & $k_{3}, c_{3}$ & $k_{3}, k_{4}, c_{3}, c_{4}$ & $k_{1}, k_{3}, k_{4}, c_{1}, c_{3}, c_{4}$ & $k_{1} \sim k_{4}, c_{1} \sim c_{4}$ \\
$9.46 \leq F R E_{7}<13.75$ & $k_{3}, c_{3}$ & $k_{3}, k_{4}, c_{3}, c_{4}$ & $k_{1}, k_{3}, k_{4}, c_{1}, c_{3}, c_{4}$ & $k_{1} \sim k_{4}, c_{1} \sim c_{4}$ \\
$13.75 \leq F R E_{8}<20.00$ & $k_{3}, c_{3}$ & $k_{3}, k_{4}, c_{3}, c_{4}$ & $k_{1}, k_{3}, k_{4}, c_{1}, c_{3}, c_{4}$ & $k_{1} \sim k_{4}, c_{1} \sim c_{4}$ \\
\hline
\end{tabular}




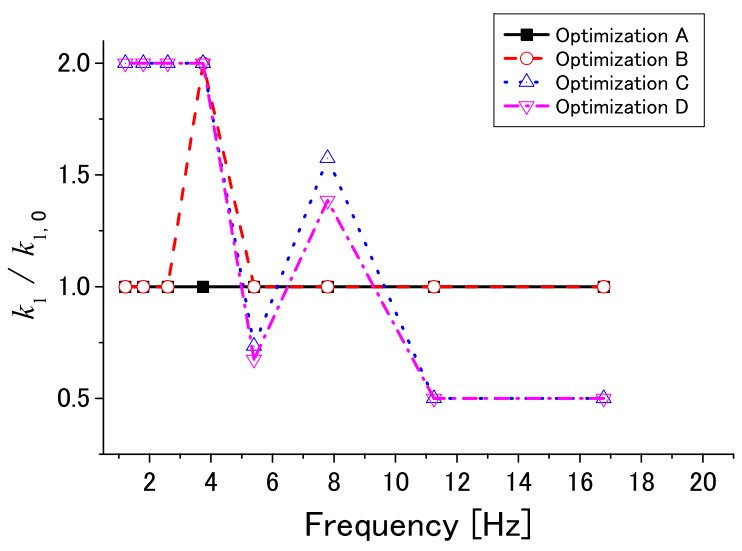

(a) The upper seat back

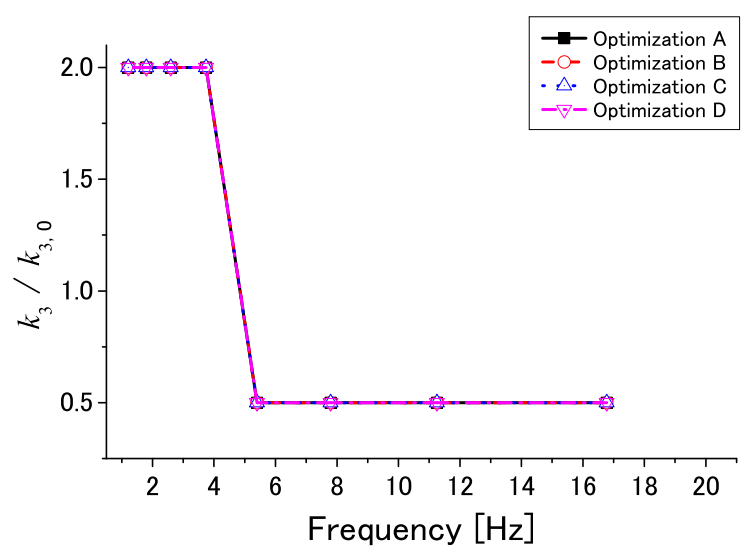

(c) The rear seat cushion

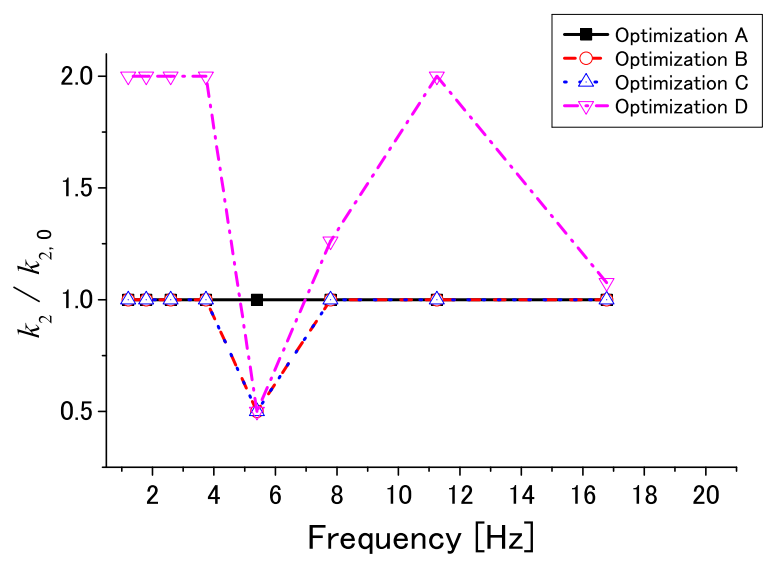

(b) The lower seat back

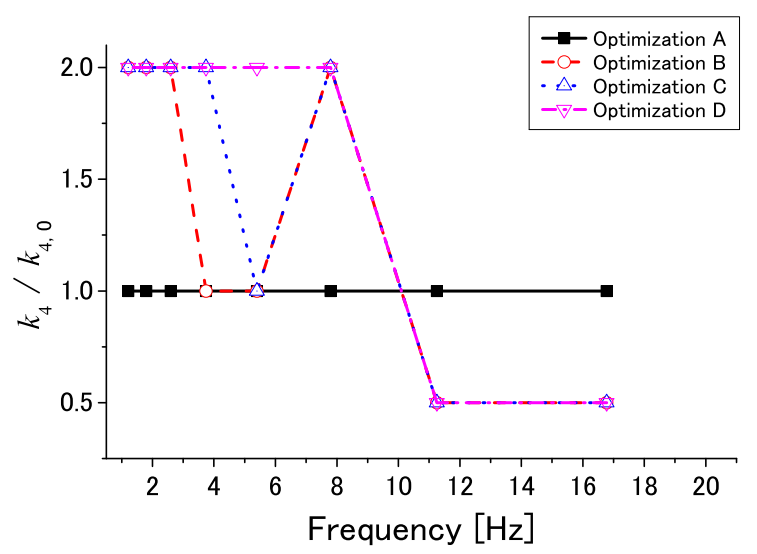

(d) The front seat cushion

Fig. 5 Mechanical properties at the seat cushions optimized

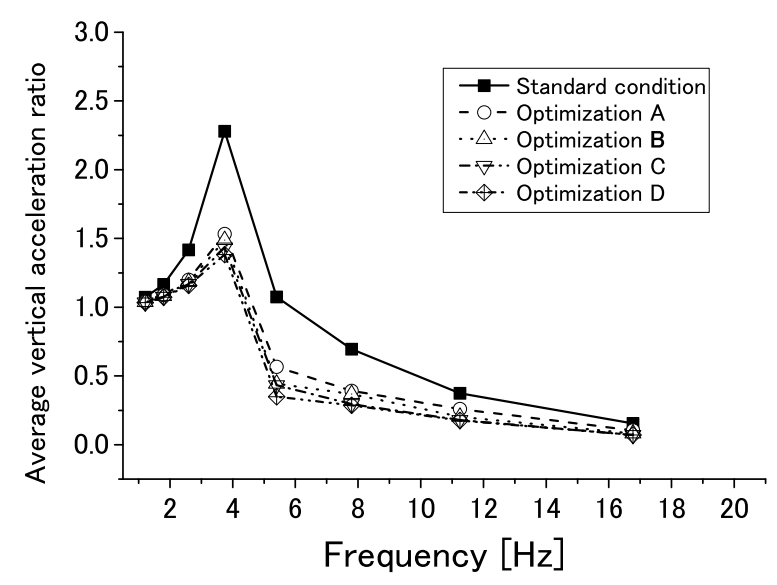

(a) Average vertical acceleration ratio

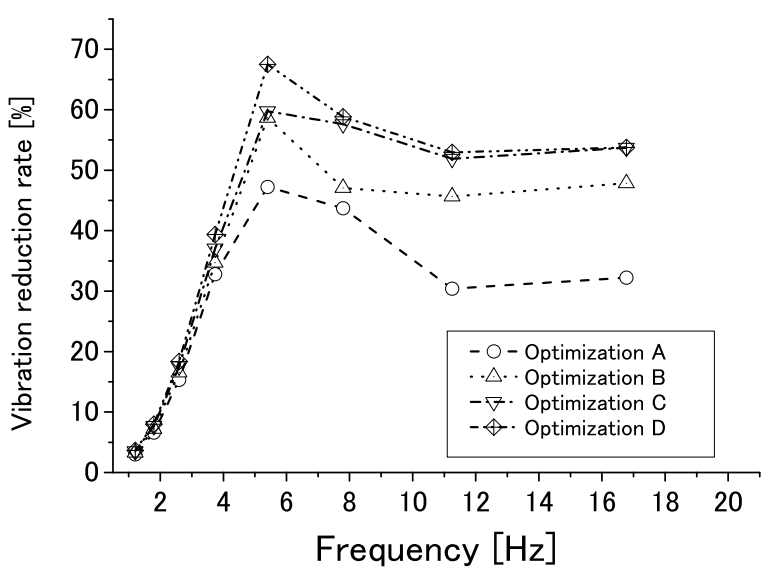

(b) Reduction rates of the vertical acceleration

Fig. 6 Vibration characteristics in the optimized seat 
文献

(1) Griffin, M. J., Handbook of Human Vibration, Academic Press, San Diego, CA, USA (1994).

(2) Makhsous, M., HenDrix, R., Crowther, Z., Nam, E. and Lin, F., ’Reducing whole-body vibration and musculoskeletal injury with a new car seat design”, Ergonomics, Vol. 48, No. 9 (2005) pp. 1183-1199.

(3) 西山修二 ,“車両 - 乗員系連成振動シミュレーションシステムの開発 (第 2 報，乗員挙動に及ぼす最終着座姿勢の影響)”, 日本機械学会論文集 C 編，Vol. 59，No. 568(1993)，pp. 3622-3629.

(4) We, I. and Chen R., "Application of an active controller for reducing small-amplitude vertical vibration in a vehicle seat", Journal of Sound and Vibration, Vol. 274(2004), pp. 939-951.

(5) Han, Y. M., Jung, J. Y., Choi, S. B. and Wereley, N. M., "Ride quality investigation of an electrorheological seat suspension to minimize human body vibrations", Proceeding Institution of Mechanical Engineers Part D, Journal of Automobile Engineering, Vol. 220(2006) pp. 139-150.

（6）西山修二，大田慎一郎，角田鎮男，小泉敏明，“自動車用シートの振動抑制装置”，特願 2010-209724(2010).

（7）大田 慎一郎，西山 修二, “ 能動制御を用いた自動車用シートの乗り心地向上に関する研究 (第 1 報, 最適化アルゴリ ズムの検証)”，日本機械学会論文集 C 編，Vol. 77 , No. 779 (2011), pp. 2601-2612.

(8) Mansfield, Neil. J., Human Response to Vibration, CRC Press, Boca Raton, Fla (2005).

(9) 西山修二 “車両 - 乗員系連成振動シミュレーションシステムの開発 (第 1 報 , 理論解析およびシステム検証)”，日本機 械学会論文集 C 編，Vol. 59 ，No. 568(1993)，pp. 3613-3621.

(10) 古庄宏輔，横家和男，藤田聡 “追突時の乗員挙動の解析 (第 1 報) -乗員の動きのシミュレーション-” , 自動車技術会 , Vol. 23 , No. 4(1969) , pp. 346-353.

(11) Dupuis, H., Zerlett, G., 全身振動の生体反応, (1989), 名古屋大学出版会.

(12) 西山修二，武田史郎，竹島透，“着座姿勢が人体各部の振動特性に及ぼす影響 (実験的研究)”, 日本機械学会論文集 C 編， Vol. 61 , No. 590(1995), pp. 3866-3873. 